\title{
“I Wish for More Than I Ever Get”: Employers’ Perspectives on Employability Attributes of Architecture Graduates
}

\author{
Susan J. Shannon \\ School of Architecture, Landscape Architecture and Urban Design, The University of Adelaide, \\ Adelaide, Australia \\ Email: susan.shannon@adelaide.edu.au
}

Received August 30 ${ }^{\text {th }}, 2012$; revised September 28 ${ }^{\text {th }}, 2012$; accepted October $12^{\text {th }}, 2012$

\begin{abstract}
This research considers graduate recruitment for architecture graduates. Employers in small, medium and large Australian firms, from the private and public sector were surveyed about their graduate hiring practices. Through distilling the discipline specific Graduate Attributes for all Australian Architecture Schools' Architecture Programs and generic Graduate Attributes for their Universities, the researcher compiled a questionnaire which was administered to prospective employers of architecture graduates. The results reveal that the possession of technical knowledge is more highly rated as a Graduate Attribute in recruitment than the possession of design knowledge/skills, and that the possession of Computer Aided Design (CAD) representation skills is more important to graduate recruiters of all firm sizes than either technical or design knowledge and skills. The research further revealed that the presentation of a portfolio is a key recruitment tool for employers, and that the demonstration of team work is a highly valued generic attribute for employers.
\end{abstract}

Keywords: Architecture Graduates; Employability; Graduate Attributes; Portfolio; Team Work

\section{Introduction}

This study of architecture graduate employers' expectations is nested within a broader exploration of the transition of Built Environment and Design graduates from University to the workplace from the perspective of graduates, employers and academics (Savage, Davis, \& Miller, 2009). This research study narrows that broader study to a consideration of graduate recruitment for Australian architecture graduates. In particular, it seeks to understand architecture graduate (public and private sector) employers' behavior and criteria in hiring graduates. It evaluates their beliefs in hiring graduates against a simplified summary of the published Graduate Attributes elicited from the seventeen 2010 Schools of Architecture in Australia, as well as the list of employability characteristics developed by the Commonwealth of Australia Government (Australian Government, 2010).

As a result it explores whether a focus on current Graduate Attributes is educating architecture graduates to productive engagement with industry at the point of graduation, and whether scarce resources are sufficiently devoted during architectural education towards the attributes currently sought by employers. In particular it focuses on the value employers place on possession of technology and technical skills in the graduate recruitment process, both as a measure of future proofing, in the sense of technical skills possibly enabling a more complete understanding of sustainability and familiarity with technology providing for more effective work practices (Australian Government, 2010), and as a key discipline-specific graduate attribute along with design skills and computer-aided design (CAD) representation skills. The key terms "employability skills", and "graduate attributes" are defined within the broader, and then Australian context to better understand these key curriculum drivers in any architectural education.

\section{Graduate Attributes}

Many universities are addressing the importance of employability skills through their graduate attributes (Nair, Patil, \& Mertova, 2009: p. 132) which the Australian government had said "provided a framework of generic attributes that ideally every graduate should have” and that "analysis of graduate attributes from a significant number of universities shows that employability skills, as outlined in the Employability Skills Framework may reasonably be seen as a subset of graduate attributes" (Precision Consultancy, 2007: p. 2). The Australian Technology Network (ATN) universities agreed that graduate attributes are "the qualities, skills and understanding a university community agrees its students should develop during their time with the institution and consequently, shape the contribution they are able to make to their profession and as a citizen" (Bowden, Hart, King, Trigwell, \& Watts, 2002).

\section{Employability-General}

Why is employability so important to Universities? Hesketh (2000: p. 46) relates that UK employers' perceptions that graduate education and training exists to prepare students for the world of work and that government, industry and students support this proposition. Hesketh says that employers are dissatisfied with the attributes of the individuals they recruit from universities. In the Australian context "employability skills are the skills required to not only to gain employment but also to progress within an enterprise so as to achieve one's potential and contribute successfully to enterprise strategic directions... Systems currently in place hold universities accountable for their 
graduates' success in gaining employment” (DEEWR, 2002 in Franz, 2008: p. 2)

At the broadest Australian level, the Graduate Employability Skills Report, presented the findings of a research consultancy which investigated how Universities develop and integrate employability skills into their programs of study; how Universities teach and assess employability skills, and how graduate employability skills might be assessed and reported on (Precision Consultancy, 2007 prepared for the Business, Industry and Higher Education Council).

Precision reflects that the Employability Skills Framework “communication, team work, problem solving, self management, planning and organizing, technology, lifelong learning, and [creative] initiative and enterprise" are seen as highly relevant to the needs of industry. "Broadly speaking industry representatives are satisfied with the technical or discipline-specific skills of graduates, but for some there is a perception that employability skills are underdeveloped. Some employers believe that universities are providing students with a strong knowledge base but without the ability to intelligently apply that knowledge in the work setting" (Precision, 2007: p. 2).

Some evidence exists about the extent to which Australian Universities are meeting employers' broad needs. The longitudinal survey of Australian youth (LSAY) (ACER, 2005) comprises 1995 and 1998 Yr 9 (15 years old) school cohorts surveyed in 2006 (when respectively 25 and 22 years old) about their employability skills (eligibility for this part of the survey hinged on whether they had completed a degree or honors degree in the previous 12 months).

"The proportion of respondents saying that the university course prepared them well or very well for employability skills was lower than the proportion saying that these skills were important/very important for all employability skills. The average gap was just under seven percentage points for the younger cohort but over 11 percentage points for the older cohort. For the 1995 cohort, the gap was largest for teamwork, communication and planning/organization. For the 1998 cohort, the disparity was greatest for communication, initiative and creativity and technology skills" (Precision Consultancy, 2007: p. 35). The data indicates that employability skills are seen by graduates as highly relevant to their roles and that on the whole they believe that universities provided them with the skills they needed although slightly less so for the older cohort (Precision Consultancy, 2007: p. 36). Precision conclude that Universities and industry, working together, can improve graduates' employability through a wide range of strategies, including improving and increasing access to Work Integrated Learning (WIL); enhancing the teaching and assessment of employability skills; and encouraging businesses to provide structured cadetships. They conclude further that through "increasing opportunities for business and higher education to work together to identify, promote, teach, assess and report employability skills" better outcomes would be experienced for all (Precision Consultancy, 2007: p. 5).

\section{The Contribution of Graduate Attributes to Shaping Graduates' Employability}

The most needed skills in the Australian labor market are the abilities to communicate, analyze and solve problems, work as a team member, tackle unfamiliar problems, and plan one's work (GCCA, 1999 in Levin \& Tempone, 2002: p. 253). Kele- her, Toft \& Howard (2006: p. 1) reported that engineering students returning from work placements favored an integrated curriculum that developed hard skills and soft [generic or employability] skills concurrently, and that this reflected the reality of what engineers actually do in the workplace. Nair and Patil (2008) and Nair, Patil, \& Mertova (2009) reported on a survey of 109 employers who recruited at least one engineering graduate in the previous 3 years. They found "a significant gap in many attributes between the expectations of industry to what graduates bring to the workforce... The three highest differences were observed for "oral communication skills", "interpersonal skills with colleagues and clients" and "written communication skills". On the other hand, "broad background general knowledge" and "general business knowledge" showed the smallest gap between importance and satisfaction” (Nair \& Patil, 2008: pp. 77-78).

Freudenberg, Brimble \& Cameron (2008: p. 159) offered a Professional Development Program (PDP) orientation to workintegrated-learning (work placements) which was "integrated into the degree program and is designed to systematically develop students' learning, employment and generic skills and supplements the theoretical studies”. Crebert (2002) reported that graduates who had experienced some form of work integrated learning, were asked to rank the top five contributions firstly the University, secondly their work placement and thirdly their current world of work contributed to their acquisition of graduate attributes (where the graduate attributes for their ranking were a pre-provided list).

1) University: written communication; oral communication; teamwork; analysis; and critical evaluation.

2) Work placement: oral communication; knowledge; written communication; practical and technical experience; and interpersonal skills.

3) Employment: oral communication; written communication; teamwork; assuming responsibility and making decisions; and practical and technical experience/interpersonal skills (tied). (Crebert, 2002: p. 139)

In summary, Universities ideally prepare graduates for employment in concert with business, as the complementary preparations provide both discipline skills and employability aspects of the broad sweep of graduate attributes. Where work integrated learning (WIL) or internships are not a feature of the curriculum, Universities alone may not be in a position to provide the ideal preparation, possibly leaving graduates with a shortfall of valuable employability attributes or "soft skills" to take into the work force and to provide as evidence of capacity to potential employers during recruitment, much as academic results and a portfolio provide evidence for the graduate attributes or "hard skills" for architecture graduates.

\section{Employability-Architecture Graduates}

There is a modest literature concerning architecture graduates' employability, with the benefits of work integrated learning (WIL) being uppermost in author's minds. Franz (2008) posits that WIL provides an opportunity to marry hard and soft skills - graduate attributes and employability attributes. Savage (2005) defends the role of WIL in developing graduate attributes, saying that the origins of institutionalized learning, as opposed to learning-on-the-job derived from the "belief emerging in the 19th century that universities taught the knowledge (the theory) that was later applied in practice... in the process 
denying, or at the very least, devaluing the role of practice as a learning environment” (Savage, 2005 in Franz, 2008: p. 166). Moreover Savage (2005: p. 4) contends that "practice knowledge is situated" and advocates "critical engagement with practice... will add to the store of knowledge that a novice can acquire prior to graduation”. Savage, Davis \& Miller (2009: p. 3) found that "graduates and employers generally agree on the importance of a set of general skills" and that of these skills 16 of the 21 were directly attributed as University developed characteristics. Of critical importance is the belief of respondents that whilst "most of the capabilities should be developed at University (76\%) versus the Workplace (14\%) and Self developed (10\%)... University plays a crucial role in ensuring graduates develop lifelong learning skills and attributes that can carry them onto a long a fruitful career, however, professionals and students [surveyed] feel universities are not doing enough to ensure this development occurs" (Savage, Davis, \& Miller 2009: pp. 13-14). Drake, Williams \& Kingsland (2003) argue that Cowdroy (1990) found in his commissioned research into architecture graduates' aptitude for practice, that "higher and more consistent skills at entry are required in Architectural Practice", and that there was "no consensus between graduates, practitioners or employers and the Schools of Architecture as to the skills required of a recent graduate" (Drake, Williams, \& Kingsland, 2003: p. 1). In their view, nothing had changed in the intervening 13 years, with schools unable to state what skills their architecture graduates possess, and employers dissatisfied with the graduates they employ. Williamson (2008: p. 608 ) concurs that practitioners give preference to students and graduates who already possess practical skills, but that academics continued to prepare students by developing graduate capabilities and life-long learning skills to equip them to survive and adapt.

Johnson (1997: p. 11) posited the same thesis 10 years prior to Williamson - that architectural education focuses on a very singular view of what an architect is- - "a design architect, preferably working in her/his own architectural practice, designing buildings with 'poetics"”. Whitman, in Wallis, Whitman and Savage (2005: p. 34) stated that "the cooperative education model necessitates a closer relationship between the academy and practice. The authors cited believe that this failure to bring practice and the academy together contributes to the gap between the expectations of practice, and the reality of outcomes from university architectural education”.

\section{Government View of Graduate Attributes}

An Australian Government perspective concerning the qualities of architects is presented in the Australian Government's Job Outlook and Job Guides which are written for an audience of Year 10 students (about to enter their final two years of high schooling) (Australian Government, 2011a, 2011b). The "Personal Requirements" for the occupation "Architects" are those who "enjoy design, [possess] creative flair, [are] able to analyze problems logically, [possess] good communication skills". The Australian Government Skills Information website (Australian Government, 2010) suggests personal attributes are also important. They state that two facets to employability skills are valued: 'personal' attributes (for example, loyalty, enthusiasm, motivation and sense of humor) and "generic" skills of communication, teamwork, problem-solving, initiative/enterprise, planing and organization, self-management, learning, and technol- ogy.

This generic skills list is was developed by the Cutler Review of Innovation created for the Department of Education, Science and Technology in 2002, and it continued to be valid in 2007 (Precision Consulting, 2007: p. 2). However, recognition of the valid teaching or learning of these employability skills is not unproblematic in the field of architectural education, with Forsyth (2007: p. 3) stating that "graduates have difficulty in recognizing these life skills [analysis, communication, problem-solving, team work] in their fine arts and design tertiary education”. Johnston (1997: p. 2) concurred, noting that in the first 3 years of Course Evaluation Questionnaires [standardized post-graduation surveys of all Australian graduates], architecture graduates recorded the lowest satisfaction rating with their course experience "of all graduates in all discipline areas...this seems to be saying that all is not well in architectural education and that there may be a fundamental mismatch between the objectives of architecture schools and the objectives and aspirations of architecture students".

The development of the generic skills subset of employability skills is an aspect of graduate attributes architecture education providers are addressing throughout Australia, although none have either expressed personal qualities as employability skills on their University Graduate Attributes website listing, nor professed to be able to develop, assess or warrant these personal qualities in their graduates. Is that important for architecture graduates? It does seem that may be the case from employers' perspectives. Cowdroy (1990: p. 23) reported that personality problems are consistently referred to by graduates, employers and personnel consultants as "the primary cause of dissatisfaction with individual graduates. Graduates and students often referred to personality problems as the primary cause of dissatisfaction with the office".

\section{The Gap for This Research}

The gap for this research study is thus identified as determining the contemporary recruitment behaviors of practices which hire architecture graduates with respect to how they prioritize the employability skills of graduates ("soft skills") and graduate attributes of the graduate ("discipline area” skills).

\section{Method}

The research design involved four aspects- the first two of which were conducting literature reviews pertaining to employability attributes and architecture graduate hiring practices. Both are reported in the Introduction. The third was evaluating the published Graduate Attributes for Schools of Architecture in Australia to ascertain what they aspire to produce in a Master of Architecture (M Arch, formerly Bachelor of Architecture) graduate. This is reported in the Results section. The fourth was conducting structured interviews with the Human Resources (HR) manager, or partner/associate responsible for recruitment at 21 large, medium-sized and small architectural practices in Australian cities (Perth, Adelaide, Sydney, Darwin) and regional centers in South Australia, and Tasmania. The public service was included through the personnel department or public servant responsible for selection of $\mathrm{M}$ Arch graduates during graduate recruitment in the State public service in a mainland state. The responses of all practices which responded to the invitation for an interview, and who employed graduates, were 
included in the results. The interviews were all conducted by telephone, by the researcher. Human Research Ethics Committee approval was obtained for this research.

The employment or recruitment factors to be explored in the structured questionnaire (which was administered during the telephone interview) were determined by the results of the literature reviews. The questionnaire employed a 5 point Likert scale to ascertain the importance of each of the factors to the interviewee. The open ended results were transcribed, coded, themed and reported thematically. Anonymity was maintained.

\section{Results for Graduate Attributes}

All Australian Schools of Architecture (Australian Institute of Architects, 2011) were contacted by telephone and email up to three times with an invitation to answer two questions "Do you have published Masters of Architecture Graduate Attributes?" and "Do you have overall University Graduate Attributes?” when Graduate Attributes for their University and Master of Architecture Program were not evident on their University and School or Department websites. Data for non-respondents was inferred from their University and Faculty/School websites.

Evaluation of the Graduate Attribute data for Schools and Universities revealed a consistency across both domains, and permitted a consolidated list of key employability skills for graduates to be inferred from University Graduate Attributes, and Government employability skills lists, and a list of key Graduate Attributes for M Arch graduates to be inferred from their Program attribute (Table 1).

\section{Results and Discussion}

\section{Interviews with Practice HR Managers and Public Service HR personnel}

Interviews were conducted with either the HR manager or the partner/associate in charge of recruitment at 21 Australian employers of $M$ Arch graduates ranging from large (>50 employees) national and international firms headquartered in Australia, through medium sized (20 - 50 employees) Australian firms (who may also accept international commissions whilst this is not a major focus of their work), to small firms $(<20$ employees) who nevertheless employ graduates, to the Government State and Federal Public Service. The firms had offices situated in Australian capitals and Darwin, as well as Tasmanian, and South Australian regional areas. Interviews ceased when the data repeated and repeated, and no new information

Table 1.

Rating of Factors prioritized in recruitment of architecture graduates.

\begin{tabular}{cc}
\hline Question & Response on Likert 5 point scale \\
\hline Priorities in recruitment & Mean score \\
Portfolio & 4.2 \\
On the job experience & 3.8 \\
Academic achievement & 3.6 \\
Curriculum university & 2.9 \\
Which institution of study & 2.8 \\
\hline
\end{tabular}

was being established, as the themes emerge from the data in this grounded theory approach (Strauss \& Corbin, 1997).

\section{Demographic Data}

Demographic data was collected from interviewees prior to asking the key interview questions. "How many staff in your firm?”; "Do you employ graduates” and "From which Universities'?

\section{Size of the Firms}

In order to engage with a broad spectrum of graduate employers, practices interviewed in the private sector ranged in size from 3 to 70 local (and 228 national) employees. Larger practices employed Human Resource (HR) Managers or Personnel Managers. In the public sector, Departments were combined with very large numbers - up to 1100 — and employed personnel staff with nominated graduate recruitment staff. In small firms the principal was responsible for graduate recruitment and selection. In larger firms, dedicated specialist HR staff were employed.

\section{Employement of Graduates}

All architectural firms' data reported herein either have in the past, or currently employ graduates, as did public sector employment sections. Reasons given for not currently recruiting graduates within the private sector were the general Global Financial Crisis-led downturn, to, in the public sector, the downsizing of the public sector and outsourcing. One large national and international firm reported that they never see a graduate for the first time, preferring to build a relationship with senior students from whom they selected their graduate intake, once they knew their potential, character and cultural fit.

\section{Recruitment from Particular Universities}

No clear sole theme emerged. The themes which emerged from coding and analyzing all responses were that for some employers local Universities were preferred and supported; that the University of recruitment choice for some employers was context dependent "It depends on why we're recruiting-what we're looking for"; and that for some employers particular University's graduates were preferred due to the desirability of a particular skill set: "I’ve always needed graduates who have some research capability - capacity of graduates to have a philosophical position — students developed research capacity during Professor X's time"; and for the same reason particular University's graduates were not employed due to them lacking required skills "Uni $\mathrm{Y}$ is not addressing what employers are looking for".

\section{Priorities in Recruitment}

In this section of the interview respondents were asked to rate the factors they prioritized in recruitment on a 5 point Likert scale where

$1=$ not important at all;

2 = unimportant;

3 = neither important nor unimportant;

$4=$ important and

5 = critically important. 
Results from the analysis of their data are shown in Table $\mathbf{1}$ below for Priorities in Recruitment Questions. Each factor was rated independently of all others.

In summary the portfolio was considered most important as a recruitment tool whilst the candidate's on-the-job experience and academic achievement were considered slightly important. The curriculum of the institution and the institution of study were less than important. The reasons given for these ratings are explored thematically.

\section{Importance of the Graduate's Portfolio}

Four themes emerged from the portfolio’s highest ranking in recruitment priorities. The portfolio shows skills as "a window to their skills", but there were wary employers wondering who did the work. They believed the portfolio must be verified to state the extent of a student's participation. Graduates must be able to present their work by making an adequate and relevant presentation and they must possess the ability to talk about their work. Employers wanted a range of skills revealed not just $C A D$ presentation renderings as they stated the content has to be honest, their own work, not just CAD: "but the difficulty is it's all presentation, not the real world".

\section{Experience of the Graduate “On the Job”}

Employers' responses grouped into these themes: that graduates [per se] were not employed-students develop a relationship with firms prior to graduate recruitment "We do not advertise for graduates. Students employed in our business may become graduates employed in our business" through to unconcern for on-the-job experience-we do not expect it"We can train, coach and mentor them so this is not that important to us". Their previous employment history provides a window to their employability for our practice "If it's available it would swing my decision towards employing them"/although other employers felt that a substantial employment decision needs to be linked with an internship rather than employment history - "Interviews are OK as an initial indicator, but the only way of really knowing them is through an internship-it's how I've recruited everyone in the past."

\section{Academic Achievement of Graduate}

Several themes emerged when considering how important academic achievement was in recruitment. Reputation/market perceptions "we take Honors reasonably seriously. Conferral of an Honors degree is seen as a good thing"; the relationship of University academic transcript to future performance indication "because what we look for is evidence"; whilst other employers differed citing their belief was that there was a lack of relationship between University grades and professional success: "Quite often people who have scraped through succeed in the profession". Employers welcomed the insight into a candidate "to see their grades, what they've excelled at". Regional employers felt that they were already restricted in who I can employ (regional) "Situation for recruitment is desperate" and therefore disregarded academic achievement.

\section{Curriculum of the Institution}

Coding and analysis revealed four overarching themes: Looking for evidence of Work-Integrated-Learning [WIL]: "Yes, it is industry exposure. Knowing they've done a good stint in a comparable practice" was valued in curricula which had WIL. Important but hard to discover: "Not always easy to discover. It's important." I don't know how I'd know: "Unknown-I have no idea about these things". Employers recognize that there is a gap between University curriculum and what we do in/need for practice: "To be honest, Universities are a lot more theoretical, we accept that".

\section{Institution of Study}

Three overarching themes were revealed. Recruit from all/unimportant: "doesn't matter". Recruitment for particular slant of curriculum: "[their graduates are] practically oriented" and recruitment locally but would recruit more widely: "we've had graduates from both [local] Universities, that's who applies, if we had grads from other Universities apply we'd consider them".

\section{Employability Skills}

In this section of the interview respondents were asked to rate each capacity on the Commonwealth of Australia's agreed list of “employability skills” (Australian Government, 2011b). These lists are also universally found in this form, or another similar form, amongst all Universities' graduate attributes.

All of these employability skills, (or attributes or capacities) were rated as more important than neutral (Likert 3) and five of them more than important (Likert 4). There is strong evidence here of the Commonwealth's oft repeated message that these generic skills are very important in recruitment, indeed as important as discipline area skills (Table 2).

\section{Team Work}

Rated mean 4.4, between important and critically important, this was the highest rating given to any of the employability skills, and was generally rated 5 , or 4 by respondents. Coding and analysis of all responses revealed two overarching themes: architecture is a team based production process "it's collaborative”/“Architecture is a team based process”; and that personality traits such as team work were hard to evaluate at an inter-

Table 2.

Rating of employability skills prioritised in recruitment of M Arch graduates.

\begin{tabular}{cc}
\hline Question & Response on Likert 5 point scale \\
\hline Employability Skills & Mean Score \\
Employability Skills & 4.4 \\
Self Management & 4.2 \\
Communication Skills & 4.15 \\
Creative Inititative and Enterprise & 4.13 \\
Planning and Organisation & 4.08 \\
Problem Solving & 4 \\
Technology & 3.9 \\
Lifelong learning & 3.8 \\
\hline
\end{tabular}


view "need referee’s reports”/“Hard thing to know from interview_-got to take a chance-but important”/“Important but never really know what you're getting”.

\section{Self-Management}

This attitude or personality trait was also rated highly by respondents at mean 4.2 (more than important) although the caveat for employers was "I know it's important but how to assess it in an interview-the referee's report is important" and from another that "You learn it in practice". Coding and analysis of all responses revealed that business-like time management is highly valued but whilst employers know that it is important, it is hard to evaluate in an interview and from other employers that they are not expecting it to be taught at University "you learn it in practice”.

\section{Communication Skills}

Communication skills were highly valued at 4.15 on the 5 point Likert scale, and employers did feel that through the interview process oral communication skills were more easily gauged, although in larger offices, it was not absolutely critical, as "there's a role for everyone”. The four overarching themes which arose were that it was unusual to find good communication skills in a graduate; that all communication skills are important (oral, written and graphic); and that it is context dependent on their role whether good [oral] communication skills are important at graduation and finally that communication is a two-way process with the office also needing to be a good communicator back to the graduate, or assist graduates from alternative language backgrounds.

\section{Creative Initiative and Enterprise}

Unsurprisingly in such a creative field as architecture, this attribute was highly valued in graduates-more than important at 4.13: "we target creative design and innovation" said one large employer, although another medium-sized employer said they rated it a 4, but recognized it was "important but impossible to pick", and by government hirer " 3 - 4"- - "how to judge it in the early stages?”

The five themes which emerged are targeting creativity; key skill for professional advancement; cannot pick it (especially in an interview); that at graduation it is early in creative career to display creativity and "we rely on teamwork"-so not everyone needs it "in employing a graduate it's not critically importantgood organizational skills may be just as important in a team work context”.

\section{Planning and Organizing}

Rated more than important mean 4.08 in graduate recruitment, planning and organising was seen by employers as a graduate's own business. Employers interviewed thought it was important, but hard to gauge in an interview. Five themes emerged: from some, that it was neither important nor unimportant due to delegation "we delegate to graduates"; from others autonomy "If they can't organise themselves...”; and that planning and organising is an important design skill to allow enough time for the scheme to be refined and finally that this attribute cannot be evaluated in an interview which leads to probation "Never sure until we see it. Often give probation”.

\section{Problem Solving}

This aptitude was rated 4, almost as highly as creative initiative and enterprise and planning and organizing with which it has something in common. Theming revealed that problem solving was hard to evaluate in an interview; that it is a skill of the profession- "problem solving is critical as they have to solve their own problems in projects they manage; [One of my] principal complaints is that they come with a problem, not a solution-go away [I say]" and by some that it is not initially important and can be developed within the office.

\section{Technology}

This aspect of a graduate's portfolio of skills was rated slightly less than important at 3.9, once interviewees understood it was not a question about representation and CAD skills as much as a question about "attitude to technology" or the "propensity to keep up with technology" which was how the researcher explained it to interviewees-keeping abreast of new technologies and being able to exploit appropriate technologies in the service of their employers. Whether employers are in a position to develop graduates' technology skills through internal or external training affects how highly employers rated it as a skill in their hiring. Three themes emerged : Attitude to technology - the propensity to keep up with technology; graphics technology - highly valued, fast changing, the University needs to do the training as it is hard to access external training; and in-house training to synthesize knowledge of technology.

\section{Life-Long Learning}

Of the eight official Commonwealth Graduate Attributes, this ranks the lowest, but is nevertheless slightly important at Likert 3.8: "all architects have got lifelong learning". The reason for this lowest ranking is that respondents universally stated that it was almost impossible to evaluate-so therefore it cannot be critical as a skill in ranking graduates for hiring. Emerging themes were that it's an attitude; the indicator for which is graduates' interest in the profession; that it is essential for our profession "all architects have got LLL"; which then presents a cost to the employer and that evaluation was difficult "How do you check this out in a grad?”

\section{Graduate Attributes-Discipline Area Skills}

From the aggregated means, respondents believed that technical skills were marginally more important than design skills, whereas the perceived wisdom in some Schools' curriculum, through literature (e.g. Johnson, 1997) and the amount of coursework time devoted to them, is that Design and Representation skills are the skills critical to graduates and the profession. This research found that employers, from a wide range of practices, and practice sizes, highly prioritise the demonstration of sound technical skills in graduate recruitment, at least equally with design skills (Table 3).

Respondents rated CAD Skills as at least equal to, or more important than, technical or design skills in graduate employment. All firms rated CAD Skills as 4 or 5 saying they were "vital”; “essential” or “you need CAD to get a start”. "It's important for graduates to come into the office conversant in CAD skills-not just creating working drawings-but 3-D-doing shadow diagrams and streetscapes" (smaller employer). The 


\section{S. J. SHANNON}

Table 3.

Rating of discipline area skills prioritised in recruitment of $\mathrm{M}$ Arch graduates.

\begin{tabular}{cc}
\hline Question & Response on Likert 5 point scale \\
\hline Discipline Area Skills & Mean Score \\
CAD Computer Aided Design & 4.4 \\
Technical Skills & 4.0 \\
Technical Skills & 3.9 \\
\hline
\end{tabular}

most typical view was expressed by a small firm "CAD skills is a 5. That's the only way they'll get in the door. When we graduated, we could draw. That's the only way we were employed. Now their CAD skills are the only way they'll be employed". Another small employer said "Revit is compulsory". Generally Revit and Building Information Management (BIM) was not a skill employers were looking for at this stage-although believing that BIM would eventually supplant CAD. Two of 21 employers already used Revit in lieu of AutoCAD.

Interviewees from the medium sized firms (20 - 50 staff) held slightly different perspectives, with one employer equally valuing CAD Skills along with Design and Technical skills, whereas another was looking to develop technical skills within the firm.

Smaller employers (less than 20 staff) need to recruit carefully, to suit their practices' exact needs now and for the future as they are often unable to share the work between a team of several employees who have different strengths in design, technical or representation skills: "they [employees] need to be good at a whole lot of things". Summarising the employer perspective of small practices was the view that graduates needed to be job-ready with the understanding of how to convert theoretical design knowledge to technical outcomes.

Employers agreed about the importance of technical skills but differed in whether they thought they should be acquired at University or not: [graduates must be able to] "demonstrate how buildings go together-[they] tend only to pick that up in the first 5 years [in their education] or "[my expectation is] basic, but I wouldn't be expecting anything beyond what they've been taught at University". Another employer said that s/he rated technical skills as a 4, as her/his expectation, and that is what s/he wants, and is not getting, stating that in terms of technical skills "I wish for more than I ever get". A senior member of the profession said in regards to technical skills, that "these days [it's] critical—-the potential to be developed—as opposed to just possessed by a graduate". This then also links to propensity for lifelong learning.

This implies is that as well as understanding how to design and put a building together technically, graduates employed in smaller practices must also be able to represent that building themselves, whereas in larger practices possibly more specialized representation staff are employed.

The analysis of CAD skills coding revealed that possession of sound CAD skills is considered a key graduating skill for employment; that a familiarity with a variety of platforms is necessary; and that a very few exceptional employers may look beyond CAD skills in employing grads-but most prefer an all rounder.

Over all practice sizes the five themes resulting from analysis of technical skills were that as an essential understanding of how buildings go together and that graduates need to be proactive in learning technical skills; as a developing skill as opposed to one already possessed, equal with design skills.

Analyzing design themes saw that design is a core professional skill: "Really important-ideas and an ability to communicate-it is what we do [as a profession]"; it is an in-demand skill; that whilst important it is rare "it's important but absolutely rare-wouldn't expect to find it in more than 1 in 3 or 1 in 4 graduates" and, although not everyone will be a design architect "not everyone's going to be a design architect but need to have a sensitivity \& interest" it is an integral part of practice. Design skills need to be balanced with more pragmatic skills: just draw it up/detail it "the principal architect produces all the designs” and that design needs to be balanced with other skills "because generally a graduate in our very small office is an all rounder”.

In some ways possession of strong technical skills underpins graduate employment opportunities as CAD skills are now the industry standard and not all employers are looking for/ or interested in employing designers-preferring graduates with solid range of other skills, and a sensitivity to design. However, having said that, some employers recruit foremost for graduates' design skills, declaring that they can develop technical skills, but rely on graduate's possession of design skills.

\section{Conclusion}

Should Universities and Schools of Architecture be more responsive to national (Government) goals and industry focus through developing curriculum to support the current desires of employers? Or is it sufficient to understand employers' current priorities in recruitment but not necessarily proactively or reactively respond to them? The solution may lie somewhere between. Without aspirational Graduate Attributes, Universities and $\mathrm{M}$ Arch Programs cannot declare their role in developing graduates responsive to future employers' needs. But with the statement of aspirational Graduate Attributes derives an obligation to pay more than lip service to them-to rationally and explicitly show the ways, and the places in the curriculum where those Attributes are developed, rehearsed and assessed (Shannon \& Swift, 2010) if the University intends to warrant that its graduates possess those Attributes.

These interviews have revealed that employers consider some of the so-called employability skills to be aptitudes or personality characteristics, which no employer declared they could instill or pre-judge in a graduate-just as no University suggested it could teach them-or perhaps more accurately warrant students have learned them in the sense of learning as transformational. Indeed, employers spoke in conclusion about those indefinable learning (in life) attitudes which are their key recruitment factors-character, broader interests and attitude. One stated:

"We do no not advertise for graduates; we have a planned and orderly rate of 1 graduate per annum in our graduate recruitment process. Students are employed in our business-and they become the graduates who are employed in our business. Our top three requirements are

1) character and cultural fit;

2) demonstration of employment history;

3) adequate and relevant portfolio (nationally profiled large employer). 
Another employer of a different scale, with 12 employees, said that "in looking at the raw recruit, I am critical of some of the people who come out of University. They are not rounded, or well educated-in all the sorts of areas to be interesting people-people with a broader interest. University is there to teach them the fundamentals, in practice we finish them off". A larger employer with 22 staff said that "[I] can't teach attitudes-but I am looking for openness, willing to learn, ready to learn. If someone has the right attitude...We've got some great graduates-not from privileged backgrounds".

An employer with 3 staff commented that "we find a lot of people have additional tertiary qualifications-lifelong learning and skills. They must have a personality fit with a small group of people and not just the office-with our clients and in public consultations."

This was also the sentiment expressed by another small practice: "I appreciate a graduate who has had a well rounded education-has an intellectual capacity. So often there is interest in 'earning a living' but what I am looking for is an interest in architecture-philosophically or internationally-even if they pursued other intellectual capacities, for example music. It is exciting to find this intellectual pursuit in a young person."

Practice agrees it has a role in the development of graduates: "As an employer, we do have some responsibility in training (we have two architecture graduates who should be registered [licensed]) but we do value people who know how to put things together as employees."

As a final conclusion, this research has revealed that technical skills are highly valued by Australian employers of architecture graduates of all practice sizes. Current sound CAD representation skills are the most highly valued discipline skills by employers, as graduates invariably have much demand upon these skills in their early graduate years. Employers look to graduates' portfolios in particular as a key presentation asset at time of hiring. Any demonstration of evidence of team work is also highly valued.

\section{REFERENCES}

Australian Council for Educational Research (ACER) (2005). LSAY cohort reports. URL (last checked 29 August 2012).

http://research.acer.edu.au/lsay_cohort/

Australian Government (2010). Employability skills. URL (last checked 29 August 2012). www.skillsinfo.gov.au/skills/SkillsIssues/EmployabilitySkills/

Australian Government (2011a). Job outlook 2011 architects and landscape architects. URL (last checked 29 August 2012).

http://joboutlook.gov.au/Pages/occupation.aspx?search=alpha\&code $=2321$

Australian Government (2011b). Job guide. (last checked 29 August 2012). www.jobguide.thegoodguides.com.au/occupation

Australian Institute of Architects (2011). 2011 architecture schools of Australasia. Canberra: AIA. URL (last checked 29 August 2012). www.architecture.com.au/i-cms_file?page=641/ASATX2011_red_mbs

Bowden, J., Hart G., King B., Trigwell K., \& Watts, O. (2002). Generic capabilities of ATN graduates. URL (last checked 29 August 2012). www.clt.uts.edu.au/ATN.grad.cap.project.index.html

Cowdroy, R. (1990). Fitness for practice: Report commissioned by the NSW Board of Architectural Education (BAE) and the Association of Consulting Architects (ACA) of Australia. Sydney: NSW Board of Architectural Education (BAE) and the Association of Consulting Architects (ACA).

Crebert, G. (2002). Institutional research into generic skills and graduate attributes: Constraints and dilemmas. Building Learning Communities through Education 2nd International Lifelong Learning Conference. Yeppoon, QLD: Central Queensland University.
Drake, J., Williams, A., \& Kingsland, A. (2003). Preparing graduates for future practice. Proceedings of the 2nd International Conference of the Association of Architecture Schools of Australasia. Melbourne: Association of Architecture Schools of Australasia.

Forsyth, G. (2007). Mapping attributes in the fine art and design curriculum. CONNECTED 2007 International Conference on Design Education. Sydney: University of New South Wales.

Franz, J. M. (2008). A pedagogical model of higher education/industry engagement for enhancing employability and professional practice. In e-Proceedings of the WACE/ACEN Asia Pacific conference (pp. 164169). Sydney: Manly. URL (last checked 29 August 2012). http://eprints.qut.edu.au/15541/

Freudenberg, B., Brimble, M., \& Cameron, C. (2008). It's all about "I": Implementing "integration" into a WIL program. In e-Proceedings of the WACE/ACEN Asia Pacific conference (pp. 159-168). Sydney: Manly. URL (last checked 29 August 2012). http://eprints.qut.edu.au/30599/

Graduate Careers Council of Australia (GCCA) (1999). Graduate Careers Council of Australia Course Experience Questionnaire. Parkville, VIC: Graduate Careers Council of Australia, Ltd. URL (last checked 29 August 2012)

www.graduatecareers.com.au/wp-content/uploads/2012/.../gca00120 5.pdf

Hesketh, A. J. (2000). Recruiting an elite? Employers' perceptions of graduate education and training. Journal of Education and Work, 13, 245-271. doi:10.1080/713676992

Johnson, L. (1997). Getting out of the sheep pen: New directions in architecture education. The International Academy of Architecture Conference. Sofia: InterArch.

Keleher, P., Toft, Y., \& Howard, P. (2006). The hard sell on soft skills. In World Association of Cooperative Education (WACE) Asia Pacific conference on work integrated learning (pp. 1-9). Shanghai: WACE.

Levin, E., \& Tempone, I. (2002). Providing guidelines for first-year assessment tasks as a means of developing core graduate attributes: Nurturing or spoon feeding? 2nd International Lifelong Learning Conference. Yeppoon, QLD: Central Queensland University.

Nair, C. S., \& Patil A. (2008). Industry vs universities: Re-engineering graduate skills-A case study. In Proceedings of AUQF 2008: Quality and standards in higher education: Making a difference (pp. 7580). Melbourne, VIC: Australian Universities Quality Agency.

Nair C. S., Patil A., \& Mertova, P. (2009). Re-engineering graduate skills-A case study. European Journal of Engineering Education, 34 131-139. doi:10.1080/03043790902829281

Precision Consultancy (2007). Graduate employability skills commissioned report prepared for the business, industry and higher education collaboration council. URL (last checked 29 August 2012). vital.new.voced.edu.au/vital/access/services/Download/ngv.../SOURC E2

Savage, S. M. (2005). Urban Design Education: Learning for life in practice. Urban Design International, 10, 3-10. doi:10.1057/palgrave.udi.9000130

Savage, S., Davis, R., \& Miller, E. (2009). Exploring graduate transition from university to the workplace: Employer, academic and graduate perspectives. Proceedings of 34th AUBEA Annual Conference: Managing Change-Challenges in Education and Construction for the 21st Century. Barossa Valley: University of South Australia. URL (last checked 29 August 2012). http://eprints.qut.edu.au/20645/

Shannon, S. J., \& Swift, J. P. (2010). Employing graduate attribute mapping to bridge the divide from education to industry. Proceedings of 44th Annual Conference of the Architectural Science Association, ANZASCA. Auckland, NZ: United Institute of Technology.

Strauss, A., \& Corbin, J. (Eds.) (1997). Grounded theory in practice. Thousand Oaks, CA: Sage.

Wallis, L., Whitman, P., \& Savage, S. M. (2005). Creating architectural knowledge in contemporary practice. Manuka, ACT: Royal Australian Institute of Architects (RAIA).

Williamson, B. J. (2008). Assessment of architectural work experience by employers and students. In e-Proceedings of the WACE/ACEN Asia Pacific Conference (pp. 607-613). Sydney: Manly. URL (last checked 29 August 2012). http://eprints.qut.edu.au/30599/ 